\title{
SELLING AMERICAN BONDS IN EUROPE
}

\author{
By Charles F. Speare, \\ Financial Editor, New York Evening Mail.
}

For another generation and, perhaps, until the middle of this century, the United States will have occasion to look to Europe for capital. We are still in the development stage. Industrially: only beginnings have been made toward the accomplishment of great manufacturing and transportation results on which will rest the future economic standing of the nation. For the past decade there has been more work to do, in building, rebuilding, equipping, transforming, enlarging, tearing down and refitting our mills and railroads than there have been domestic funds with which to do it. The balance has been drawn from the surplus capital countries of Europe. This condition shows no sign of change. It would be easy to spend a billion dollars annually on American railroads alone for the next ten years and then they might not have sufficient capacity to meet the traffic demands of 1920 . As much more might be put into the steel mills, the smelters, the cotton goods factories of the South, the implement producing plants, the car and locomotive and the electrical shops in the four corners of the land, and after all this was done, they would only be on a fair economic basis and barely able to turn out their maximum capacity in reasonable time. So, with our agricultural wealth rising each twelve-month, products of our gold, silver and copper mines increasing rapidly in value, our exports to foreign countries advancing steadily, there is all the time an offset in capital consumption to more than balance the scales on which is placed our new wealth. Without the accumulated and unemployed pounds sterling of the Englishman, the francs of the Frenchman, the Belgian and the Swiss, the guilder of the Dutchman and the marks of the German, the material progress that has been the lot of these United States ever since the close of the Civil War could not continue.

The foreign investor is necessary to the American banker. $\mathrm{He}$ has been the means of turning many a bond offering from dismal failure to partial success. The international bankers have cultivated him for the last fifty years and know that he will often(269) 
times take securities that the American rejects and that he usually gets his reward in a heavy profit. He frequently has more foresight, better judgment, even more detailed knowledge of American railroad and industrial properties than the man at home. His vision is less clouded, his perspective more accurate, because he does not include in it the disturbing minutiæ of finance but concerns himself with the fundamentals. Just as an European often has a clearer idea of American politics than a New Yorker or the man of average information wherever located in this country, simply because he sees only the broad movements in state and national affairs, so the investor in London, Paris, Amsterdam or Berlin judges better of the value of an American railroad bond, about which he knows the essential facts and from which all sentimental speculative influences are stripped, than the native investor who sometimes stands too close to the ticker when taking the measure of his bond.

Back of the average good judgment of the foreign investor is a vast amount of patience and willingness to give his investment a fair trial. Bonds that go from the United States to Europe usually stay there until they mature or the profit on them is so large or the interest yield so low, due to the premium they command, that they are no longer desirable to hold.

An instance of this has been given in the case of the United States 4 per cent bonds of 1907 which have just been redeemed. The bonds into which the maturing issue was converted were originally placed abroad in the 70's by the Rothschilds. Most of them went to Holland and to Germany, particularly to southern Germany where Frankfort was then the financial center of the empire. Blocks of the bonds have just been released. In Holland last year I came across several lots of Chicago \& Northwestern and Chicago, Milwaukee \& St. Paul divisional bonds that have been held for thirty to thirty-five years. The European man of means takes great pride in seeing his estimate of a property fulfilled, and he rarely abandons an investment until it has made good or shows itself to be utterly worthless. Many times, during the reorganization period of fifteen years ago, investors on the other' side paid their assessments when the American balked at it. They lived to see their judgment vindicated and profits of great size credited to their account. 
My subject has to do with the selling of American bonds in Europe. Included in this are the history of the introduction of bonds of American issue into foreign countries with a surplus for investment, the probable extent of the investment of different European nations in our securities, the ebb and flow of foreign capital in American securities, the ways in which bonds are placed on the markets of Europe with some suggestions concerning the method of facilitating the distribution of bonds among the small investors on the Continent. Treatment will also be made of that fascinating aspect of the whole subject, the French market and the pioneer work necessary in order to fertilize well that lucrative field for the American bond dealer.

For over forty years now the names of English, German and Dutch investors have been on the books of American banking houses. ${ }^{1}$ Whatever figure might be named of the par value of the bonds placed abroad in that time would be guesswork. It would reach up into billions of dollars. The movement began when this government started to find a market for its bonds at the end of the Civil War. The country was poor enough then there were few men with capital to spare for investment, and suspicion of the permanent credits of the government prevailed in many conservative quarters. But the Dutch bid eagerly for a 6 per cent bond, guaranteed by the United States of America, which was offered at 60, and, therefore, returned them an income of just ro per cent. Large blocks of these bonds were sold throughout Holland. The German investor, particularly the wealthy South German bought the sixes, too, with avidity and held them until they were redeemed. In most cases the proceeds of these bonds were converted into cash which was, in turn, placed in the 7 and 8 per cent bonds of such American roads as Chicago \& Northwestern; St. Paul ; Illinois Central; Great Northern; Norfolk \& Western; Central Pacific; Union Pacific, and Missouri, Kansas \& Texas. These bonds were subscribed to between 75 and 85 . As a general rule it seemed to be felt, in those days, that the United States was on about a Io per cent interest basis.

The English investor came on the scene at a later date. But when he did take part in the absorption of American securities

1Early financial history contains the record of sales of American governments to Dutch bankers by Alexander Hamilton, then Secretary of the Treasury. 
he did so on a very liberal scale. In the late $70^{\prime}$, but mostly between 1880 and 1885 , and again between 1893 and 1898 , his purchases were enormous. It is estimated that, in the decade between $I 880$ and I890, $\$ 3,000,000,000$ of English capital went into foreign enterprises. I should say that fully 50 per cent of this came to the United States. The control of three-fifths of the American railroads was held in London. Not only the bonds but stocks of these properties were bought in quantity. America seemed to the English investor of those times the one profitable field for his funds. Our strongest banking houses had made good connections on the other side and they were able to secure the confidence of the distributing agents for the best class of bonds current. In committing themselves so exclusively to one country's securities the English made a bad mistake, and the panic of 1893 cost them tens of millions pounds sterling. They are now much more discriminating buyers than they have ever been and look more to steady income than to big speculative profits.

France is a comparatively new field. So far it has scarcely been touched and holds out the greatest possibilities of any in Europe. But it is peculiar territory and a difficult one to work and I am not sure but that conditions which now make it seem so attractive to the distributor of bonds will entirely change in another ten years. An industrial revival in France, demanding a large amount of domestic capital, would quickly absorb the annual surplus of the nation. However, it may be too much to suggest that France will ever imitate Germany, or Belgium and derive an income of any size from anything other than her crops, wine, silks and the free-spending tourist.

Different considerations enter into the sale of American bonds to the English investor from those obtaining, for instance, when the investor in Holland is approached. It is much easier to interest a German in our securities than it is to secure attention from the Frenchman. Each looks at the question from a slightly different point of view. Investment traditions, local prejudices, the amount of income yield that will satisfy the prospective buyer, relations between government and investor, taxes on securities, the attitude of banker toward his client and the current state of the market which the seller of bonds is approaching with his wares are all factors to be considered. 
Investment conditions have been changing throughout the entire world in the past two years. In a magazine article a year ago I had occasion to point to the fact that investors who, at the beginning of the twentieth century, were content with a yield of 3 to $4^{1} / 2$ per cent were then demanding from 4 to $5 \frac{1}{2}$ per cent. This was due to several economic changes that had taken place. One was the higher cost of living which made it impossible for the income of 1906 to do the work of the income of 1895 . The man with $£ 20,000$, for instance, invested in British consols yielding about $23 / 4$ per cent, had to economize severely, whereas his annuity of $600 \mathrm{had}$, in other days, made him very comfortable. Further than this, under the influence of a rapidly rising gold production, the highest grade bonds were the ones in which the greatest depreciation occurred. British consols, for generations the premier security of the London market, and the financial barometer of international exchanges, dropped 30 points, or more than much less exalted issues. So the investor took the wise stand that, if the very best bonds could not be guaranteed against severe shrinkage he might as well place his funds where they would yield more and possibly suffer no greater decline. Therefore, instead of consols, he bought the 6 and $4 \frac{1}{2}$ per cent issues of the Japanese government which yielded him from 5 to better than 6 per cent and have, since flotation, fluctuated less than half as much as British consols. In place of old line British rails like Northwestern, Great Western, Brighton, etc., whose stocks have gone down from 60 to over 100 points in recent years, from a level that returned under 3 per cent, the British investor bought notes of American railroad companies which could be had to return an average of 6 per cent. German investors at about this same time refused to consider government issues on a $3 \frac{1}{2}$ per cent basis and they carried their point. Dutch investors have always demanded a good income, say 4 to 5 per cent, and they began to select securities that bore $1 / 2$ to I per cent more. The French investment customs surround both Belgian and Swiss investors who similarly refused, after they had been able to get Russian bonds on better than a 6 per cent basis, to be attracted by the low interestyielding securities which exclusively filled the portfolios of their ancestors. The rising credit of new countries, like the United States, South America, Canada, South Africa and Egypt and of former third-rate nations, as Spain and Italy, brought into competi- 
tion with the ranking securities of the older empires a great quantity of bonds which were perfectly safe and had the distinction of providing a satisfactory yield. This condition is a fairly permanent one. Never again, I believe, will the pulse of the markets of the world beat in unison with the fluctuations in British consols and more and more, in spite of the deep patriotism that inspires the French investor, will the rente cease to be the channel into which the thousands of small investors turn their annual surplus. Germany is constantly clamoring for better returns on her money which the competition of trade and of broadening foreign markets incites. Holland invests perhaps too great a percentage of her income away from home because she wants as big a yield as possible. And this is the tendency prevailing whenever there are securities to be bartered for cash.

The insurance companies are the largest English buyers of American bonds. At the time of the San Francisco fire it was shown how vast the amount held by these institutions had grown to be. Most bonds are placed through the London agents of American banking houses or by their own branch offices. The English and the Scottish banks are also buyers on a large scale when the market seems to offer good opportunities. Bank purchases are invariably for the clients of the institution who have intrusted the selection of their securities to their banking adviser. The vaults of most of the important English banks contain a fair representation of high-class American railroad first mortgage and prior lien bonds. There are also in England companies that purchase American issues and issue their debentures against them, and from the profits on their holdings, pay interest on their own shares. Quite a bit of capital is invested in this way. The English market is pretty well scratched over. Englishmen do not have to be told about American railroads or of the best of our industrials. The question with them now is mainly one of yield, for they have a strong faith in the general destiny of the United States and are not afraid to invest their funds here when they can get the proper terms. It might be said of them that, latterly, they are more inclined to take hold of tested and tried bonds than invest in junior mortgages which have still to make their record.

It is on the Continent that the great future market for American bonds lies. That this fact is appreciated is shown by the num- 
bers of representatives of American houses who have traveled there in the past year and a half sounding the people and trying to tap their reservoirs of capital. Wide-awake firms are establishing agents in all of the leading centers of Holland, Germany, Switzerland and Belgium, and there are already a half dozen branches of New York and Boston bond houses within a radius of a mile of the Bank of France in Paris. Instead of writing their circulars of bond offerings in the English language exclusively the up-to-date bond dealer to-day has to put it into French and German as well.

Circularizing is a popular form of bond introduction in parts of Europe. It pays in Holland and in Germany where a good deal is known of American conditions and also in Switzerland, but I regard it as a waste of time in France until more preliminary work of a pioneer sort serves to give the investor of that thrifty nation a closer acquaintanceship with our institutions, our corporations and our methods of financial operation.

While hundreds of millions worth of American bonds are held in Holland (and bonds that go to Holland stay there indefinitely, so that the aggregate of them is all the time rising) only a small percentage of the Dutch investors who buy American bonds from preference ever see them or cut the coupons from them. The Dutch method of investment is similar to that which exists in smaller form in England. What are known as "offices of administration," which are directed by some individual banker or group of banking-houses, exist. They take the funds of the investor and buy certain securities with them. Suppose, for instance, that the purchase was Union Pacific first 4's. Against this the investor receives a certificate of the "office" with an attached coupon. When the Union Pacific coupon falls due in January and July the corporation collects it and credits it to the account of its client. The client cannot exercise any voting privileges. These are waived in favor of the administrators. Of course, the latter would be controlled by the prevailing sentiment of their clients on any important decision. For the work they do the "offices" receive a commission of $1 / 4$ of I per cent. Another type of concern is that which purchases American and other foreign interest-bearing securities and issues its own 4 per cent debentures against them. These companies are patterned after the mortgage banks of Germany and the French Credit Foncier. 
They have been very successful and have rarely defaulted their interest.

Holland will always be a good field for American bonds. The Dutch have made money in them and are satisfied with the yield. They have been steadily liquidating the enormous mass of Russian bonds (at one time estimated as high as $\$ 500,000,000$ ) and placing part of the proceeds in our securities. The country is rich in colonial possessions from which its income ranks only second to that of Great Britain. The people are economical and live to save and gain a competency. It is this quality of temperament that makes of Holland one of the great surplus capital countries of the world.

Going over to Germany we find that investment conditions there have their own peculiar forms. The great banks of issue figure prominently in all of the underwritings and the flotations of securities. They can, in many instances, make a bond go or they can blackball it with the investor. There are, of course, separate groups of banks which are more or less in competition with each other and constantly offering different lines of bonds. But there is not the pulling apart that is exhibited by the American banks which remind one of the "two and seventy jarring sects" of the Rubaiyat. They are a unit generally on fundamental questions of finance and one would not find one group taking a diametrically opposite stand from another group on the expediency of national investment in the securities of a foreign nation whose affairs just then happened to be passing through a critical stage. The Deutsche Bank, the Dresdner Bank and the Disconto-Gesellschaft, with an annual turnover of about $\$ 50,000,000,000$, are the great distributing mediums for Americans as well as for all other foreign issues. The Darmstader Bank has very close connections with banking firms in the United States which place a great many bond issues on the market, and the new American Bank in Berlin was formed a year ago especially to facilitate the placing of American securities in the hands of the German investor.

The original field of activity of the American bond dealer in Germany was in the southern part of the Empire. Frankfort was a ready buyer of American bonds long before the north German had any acquaintance with them. This was due to the success that had followed the placing of American governments in South Germany and the profits that had accrued from some of the western 
railroad mortgages in the ante-receivership period. The family connection, too, between South Germans and the German banking interests in New York did a great deal to establish our best issues in the region of which Frankfort was the distributing center.

Now the Berlin banks are the power to be reckoned with. They have made a very successful propaganda in American bonds the past few years. It may be said without hesitation that no underwriting syndicate is ever formed to bring out an American bond or note issue but that the big Berlin banks are allowed to participate in it. They carry on their campaign largely through circulars. These they send to their regular clients, who number thousands, and to the countless small banks and private banking firms throughout the empire. They do a great deal of advertising, too, in the public press. The Berlin banks have taken the initiative in securing admission to the Berlin Boerse of the few American issues listed there. There are less than thirty American bonds now quoted on the Boerse and only three or four American stocks. Listing is a very expensive operation. It cost the bank, which was the sponsor for the Pennsylvania $3 \frac{1}{2}$ convertibles put on the Berlin Boerse a few years ago, something like 100,000 marks to complete the work. A good part of this was in the advertising which is required before the bonds can be located. Then the Boerse authorities demand an inexhaustive report on the property whose bonds are up for listing. In the case $I$ have cited this statement covered twenty-five long printed pages. The difficulty surrounding the listing undoubtedly accounts for the small number of American issues regularly quoted in Berlin.

The German investor asks a fairly good income on his capital. He likes his own railroad and municipal issues and will take them in preference to any other bonds, income being equal. One objection that he has to American bonds is that they have a constantly changing title. The transition of the first mortgage bond into some junior issue, as reorganization necessities arise, the creation of newfangled types of bonds, as the "convertible" or the "collateral trust," do not meet with the approval of the German banker or his clientele. "You wrap the original bond in many coverings like an onion," a Berlin banker said to me, "without giving new value to the bond or creating fresh assets for the security." To get back to the original issue would require the most expert bond advice. The 
investor who buys a bond which is nearest possible to the road and sees it transformed into several different types, finally begins to wonder what his equity is should he need to exercise it. This is one great drawback against the popularizing of American bonds throughout Europe.

Switzerland is a smaller market than those we have been dealing with but one that has a good surplus for investment and is friendly to Americans. I am told that about 75 per cent of the bond business with the United States is done through one house which has been selling bonds to the Swiss investor for a quarter of a century. The Swiss Bankverein is one of the large distributors and a subscriber to most of the best underwritings. The Swiss likes his own state railroad issues and wants about the same income as the German and the Dutchman. Geneva, Zurich and Basle all have exchanges on which are to be found a fair number of American securities and the leading Swiss newspapers carry quotations of bonds of our railroads.

The fascinating feature of the French market, from the point of view of the average American dealer in bonds, is that it is unexploited. It is fallow ground from which fair crops may be harvested if the right kind of seed is sown there. It is a market worth making a great deal of effort to cultivate. The French are the thriftiest of the investing people of Europe. The Italian lives as closely and saves as much in proportion to his income. But he is not an investor in securities. The yearly surplus of France, available for investment, must be some milliard francs. At various times in the past two or three years there has been an uninvested supply of capital to French credit of from $\$ 400,000,000$ to $\$ 600,000$,ooo. Thrift is the national virtue. It is practiced by everyone and is a means to an end,- that end being independent old age, a marriage dot for the daughter and a portion, at maturity, for the son. The "woolen stocking" of the French is proverbially well lined. From it was drawn the billion dollar indemnity that Bismarck imposed on the Republic at the end of the Franco-Prussian war and which he expected would be a load under which France would be crushed. The debt was liquidated in surprising time. Then did Europe appreciate first of all the saving quality of the French and the amount of their reserves constantly in hand. It was a revelation significant to borrowing nations of the Continent, and from that 
time to this, France has steadily been petitioned by borrowers to place a part of her funds in their bonds.

This appeal has resulted in the investment of nearly $\$ 2,500$,$\infty, 000$ in Russian bonds alone. France has been Russia's banker almost exclusively for the past twenty years. Naturally, having invested so liberally in government issues, the French were attracted to Russian industrials. In them their experience has been unfortunate. While they have never lost a coupon on Russian funds, though the market value of them has greatly depreciated since the Russo-Japanese war, they have lost interest and much of their principal in ventures of other sorts. Mining shares particularly have been the bete noir of the French. Some Russian mines, bought at I,200 to I,500 francs, have shrunk to a few hundred francs. Spanish mining securities, too, have been unprofitable. On the whole, however, the Frenchman has taken as his motto: "Buy industrials if you would live well; buy governments if you would sleep well," and adhered to the last half of it. He has been content with the smallest yield of any investor, and consequently the great bulk of his funds has gone into the very safest issues on the market.

Alfred Neymarck, the eminent French statistician, estimates that the total securities held by the French people approximate $\$ 18,600,000,000$. The population of France is about $40,000,000$ souls, so this means a per capita investment of $\$ 465$. The wealth of the country is placed at $\$ 35,000,000,000$. About $\$ 13,000,000,000$ are represented in foreign investments. The value of foreign investments made in 1906 alone was $\$ 850,000,000$. The Frenchman is prone to locate his funds where the tax collector cannot get at them. While the wealthiest in regard to available capital, France is the sorest taxed of any nation and is continually raising her assessments on her people to meet deficiencies in the budget caused by official extravagance. It is reckoned that the value of the yearly income of the individual is absorbed by taxes within six years and his capital in fifty years, and some economists claim that the fortune left by parent to children is wholly exhausted by taxation in less than a generation. The fisc is the hobgoblin of the rentier. Every means known to human ingenuity is resorted to in the attempt at evasion of taxes and keeping secret the personal effects of the individual. We know how quantities of securities are held in this country to the credit of the Frenchman so that he may not 
have to pay the government and bourse taxes on them; how a year ago there was a steady outflow of capital and securities from France into Switzerland and Belgium until the rate of exchange of Swiss and Belgian cities on Paris moved in their favor,- -an uncommon occurrence. The inquisitorial policy of the government threatened to exhaust French markets of capital and the export of capital was one of the influences which determined the higher discount policy of the Bank of France. Socialism, which is rising more rapidly in France than elsewhere on the Continent, has its terrors for the French investor and makes him loath to place his funds in bonds or shares that might be affected by political or social revolutions.

This antipathy to home issues is stronger now than ever, and coming at a time when the rentier is beginning to doubt the wisdom of having so large a part of his principal in Russian bonds, it gives splendid opportunities for the American bond dealer to drive home his arguments and enter a wedge that cannot easily be dislodged. The Pennsylvania Railroad loan of $\$ 50,000,000$ placed in Paris in 1906 and now listed on the Paris Bourse and the loan of $\$ 29,000,000$ of the New York, New Haven \& Hartford Railroad have broken the ice. As money conditions the world over improve there will, no doubt, be other issues located in Paris and quoted there on the official sheet of the Bourse.

The bond dealer in the United States who is eager to place securities in France should first study the type of investor with whom he is to deal. The unique personality of the French rentier makes exploitation in France much different from that in any other country. His character is peculiar and without parallel. Individually the French investor's influence is infinitesimal; collectively his power penetrates the money markets of the world and determines their rate of interest. Saving is taught the French boy and girl just as soon as they are able to appreciate the value of money. The schools make economy a virtue and an incentive. Thrift is a quality which, if strictly practiced, brings its reward in the form of ten-francs books of deposit at the end of the term. The government savings banks get these first few francs. The limit of deposits in them is $I, 500$ francs $(\$ 300)$. When this sum is reached it is reinvested by the bank authorities for the benefit of their depositor in 3 per cent rentes. These banks are very popular with the peasants, farmers and small shop-keepers who have already bought 
with their savings, since about I880, when France began to show a surplus, $\$ 4,300,000,000$ of rentes. Of the total French debt in 1905 of $\$ 5,878,822,695$, the sum of $\$ 5,005,246,780$ was held at home.

In addition to the government savings banks there are the postal savings banks, different organizations that make a specialty of receiving the funds of members and of investing them, and finally, the great credit banks with headquarters in Paris and branches that touch every district and parish in the Republic. These institutions, of which the Credit Lyonnaise, the Société Générale, the Comptoir Nationale, the Banque de Paris et des Pays Bays and half a dozen smaller concerns are most notable, are the great bond-distributing forces of the nation. They form the syndicates that take over immense issues of Russian colonial or American bonds and place them with their clients. The Credit Lyonnaise has nearly 450,000 individual accounts, while the aggregate accounts of the five big Paris banks is close to one million. The managers of these institutions become very intimate with their depositors. It is their judgment which determines the character of the bond into which the funds of the client go. The implicit confidence that the rentier places in his banker or "agent de change" is one of his most astonishing qualities. It is a confidence rarely misplaced.

The great handicap to placing American or any other foreign securities in France is the high tax imposed on all bonds or stocks listed on the Bourse. The taxes are three in number, viz., a stamp tax, a transfer tax, and an income tax. It cost the Pennsylvania Railroad about $\$ 200,000$ to list its bonds in France. This will be the yearly impost, exclusive of the cost of collection and the commission to agents, so long as the bonds live and the present laws exist. The stamp tax may be paid in full, amounting to $\$ 1.20$ per $\$ 100$ face value of the sum issued in France, or six cents per $\$ 100$ per annum, payable quarterly. This tax must cover the number of securities to be issued in France. For stock this amount cannot be less than one-tenth of the capital and for bonds one-fifth of the total amount outstanding. On coupon bonds the annual transfer tax is one-fifth of I per cent on the average price of the year preceding taxation. The income tax is 4 per cent on the revenue. The transfer of a bond from one estate to another, in the event of 
the death of the holder, calls for a tax of 2 per cent. Summing up the whole effect of the taxes we find that it amounts to about four-tenths of I per cent per annum. In other words, bonds that could be sold flat in New York to yield 4 per cent would only bring about 3.60 per cent in Paris.

Efforts have been made to remove or commute these taxes, but with no success. They will probably stand for some years to come. The American banker must take them into consideration if he would enter the French market. There is, of course, a loophole. This is provided by carrying bonds owned by French investors in the country of issue. It is being done now with some success. But it will never get beyond certain proportions. The small investing class would not buy bonds that they could never see or from which they could not personally cut the coupons. They like to have and to hold their bonds; to see the physical substitute for their slowly accumulated savings. In time it might be possible to issue French bonds against American holdings, but I doubt whether this, even, would be very popular.

It is difficult to impress on the American the small supply of capital that the individual French investor, towards whom the former is working, possesses. Perhaps this may be done by showing the value of individual holdings of French rentes. The investors in rentes who receive less than $I, 500$ francs $(\$ 300)$ income annually are more than $3,000,000$. There are over 600,000 who draw less than 30 francs (\$6) income a year, and no fewer than $1,600,000$ who derive a revente of but 20 francs $(\$ 4)$ from their investment. The income of 30 francs means an investment of 1,000 francs or $\$ 200$. This brings forward another matter of detail to which the American will have to look sharply before he makes a success of the French flotation of his bonds. He must issue bonds of small denominations. Bonds of $\$ 500$ and $\$ \mathrm{I}, 000$ par value will not sell to any extent in France. Issues of $\$ 100$ or $\$ 200$ ought to be the maximum size where popular subscription to them is sought. A third detail-and this would be a natural sequel of the listing of the bonds on the different bourses-is the desirability of having the bonds quoted daily in the papers which reach the bulk of the French people. The Frenchman likes to see his bond quoted and to know each day what it is worth. It is claimed that, in order to get a bond listed in France, the press has to be bribed-"sugared" 
they call it-and that this bribe, sometimes as high as 2 per cent, should be added to the cost of listing. I do not know about this. What $I$ do know is that American bond dealers have been guilty of selling in France,bonds at from 2 to as high as 8 and ro per cent above the regular quotation on the New York Stock Exchange. They could not do this were the prospective buyer provided with an official quotation of his favorite issue.

As near as I can estimate, from figures procured in the most reliable quarters in Europe, the gross holdings of English and Continental investors in American securities-and the bulk of these is represented by bonds-are valued at from $\$ 6,000,000,000$ to $\$ 6,500,000,000$. Of this Great Britain, whose foreign investments are said to be more than those of all other countries, holds $\$ 4,000$,000,000 ; Germany $\$ 1,000,000,000$; Holland $\$ 600,000,000$ to $\$ 700$,, 00,000 , though Mr. Hill, the American Consul at Amsterdam, puts the figure much lower; France $\$ 300,000,000$ and Switzerland $\$ 100,000,000$. M. Leroy-Beaulieu believes that French capital will flow into American securities in increasing proportion as the years go on, and that, in another decade, the investments of France in the United States will be greater than in any other country save Russia. Not all people agree with M. Beaulieu on this subject, but the French promises are bright. So they are from Great Britain, Germany, Holland and Switzerland. For a generation money will be in good demand here and interest rates will average higher than in Europe. The best income, therefore, will be on American securities; and as the European investor is gradually being educated to better returns on his capital, he will look westward for the field in which to place it to best advantage. Whatever the absurdities of our currency system and the irregularities of some of our high financiers, the investor abroad realizes that these things cannot destroy the country's wealth or exhaust her resources, and that the trend of values here, barring some interruptions, is upward. 